\title{
Noun Class System in Ikhin, an Edoid Language
}

\author{
Olaide Oladimeji \\ Department of Linguistics and Languages, Federal University, Oye-Ekiti, Ekiti State, Negeria \\ Opoola Bolanle T. \\ Department of Linguistics and Languages, Federal University, Oye-Ekiti, Ekiti State, Negeria
}

\begin{abstract}
This paper examines the noun class system in Ikhin, an Edoid language in South-South, Nigeria. Unlike other related Edoid languages examined and investigated by various scholars, nothing has been said on the noun class system in Ikhin. The paper establishes noun prefixes and concord prefixes in modifiers such as demonstrative and possessive pronouns. Although inherited, this paper confirms that majority of the nouns are inflected for number by means of prefix vowel alternation. The study also confirms that the language maintains most of the noun class distinctions in Edoid languages. The paper examines morphological alternations and their implications for phonology. It is argued that vestiges of vowel harmony appear in the patterning of vowels in nouns and in the way vowels alternate in prefixes. Vestigial evidence of concord which is normally the hallmark of a noun class system in Edoid languages was discovered in modifiers such as demonstrative and possessive pronouns.
\end{abstract}

Index Terms — noun class system, Ikhin, Edoid language, concord prefixes, morphological alternation

\section{INTRODUCTION}

The name of the founder of Ikhin is Ekpenga. He was one of the three sons of the Oba of Benin who left Benin City as a result of disagreement with their father, King Ewuare of Benin who ruled from about 1440-1475. The other two brothers were Ekonkaran and Iguan. They packed their belongings and headed West Ward from Benin but had no specific destination in mind. The disagreement arose as a result of their opposition to their father's practice of enslavement as a source of labour for building his palace and his insistence on the use of of palm oil instead of water for mixing the mortar. The three brothers; Ekpenga, Ekonkaran and Iguan finally settled at Ifon which is now in Ondo State.

They sojourned at Ifon for about half a century. During this period, the three had increased in population but refused to imbibe the Yoruba culture, therefore, the people asked them to leave. Ekonkaran and Iguan were the first to leave. Ekpenga remained. As he continued to stay, Ifon people became more worried and began to ask "what type of people are these"? Ekpenga usually replied in Bini thus "Edo Mikhin", that is "I am from Edo". Therefore, in discussions and conversations, the people of Ifon instead of saying "Edo-Mikhin people" would refer to them as "Ikhin people". From such interplay, Ekpenga and his household earned the name "Ikhin" before they left eventually to settle at UHOMOERUE. That was how the name Ikhin originated.

Ikhin is one of the languages spoken in the Southern Nigeria. It belongs to Edoid language family. According Oladimeji (2013), it is a daughter language that belongs to the North-Central group of Edoid languages that was formerly known as Eastern Kwa. Categorically, Oladimeji (2010) states that the Ikhin language is spoken at Ikhin in Owan East Local Government Area of Edo State. For Blench (1989), the Eastern Kwa languages are recently classified as Benue-Congo (BC) and they form putative West Benue-Congo (WBC). However, the Edoid languages are majorly grouped into four. For Lewis (2013:160), they are North Central (NC), Northwestern (NW), Southwestern (SW) and Delta (D). Additionally, Elugbe (1989) recorded that the Edoid languages spread from the eastern Niger Delta in the Rivers and Bayelsa States through Delta State and Edo State into parts of Ondo and Kogi States (http://www.ling.mq.edu.au).

This study investigated the morphology of Ikhin with a view to determining the typology of its noun class system. Ikhin has similar linguistic features with Edo (Bini), Emai and Ghotuo languages. Elugbe (1986) and Egbokhare (1990) have both discussed noun class system in Ghotuo and Emai respectively. Emai,Ghotuo and Ikhin are spoken in Owan East Local Government area of Edo states. There is no mutual intelligibility among the speakers, because, each has its own linguistic peculiarities. This paper discusses morphological alternation and its implication for phonology as it relates to the analysis of noun class system in Ikhin.

Granted that some elementary concepts (such as morphemes, morphs, allomorphs, affixes, etc.) in morphology can be understood quite adeqautely without any real references to the other aspects of linguistics, it is however, rare to grasp the full implications of contemporary research in mophorlogy without a requisite knowledge in phonology and syntax. Egbokhare (1990:74) refers to morphology as a lower-level syntax "because both syntax and morphology involve syntagmatic relations of some kind". Syntax has as its frame of reference, the sentence as a unit of relationship 
involving words. Morphology on the other hand, has as its frame of reference, the word as s unit of organization involving morphemes.

The grammatical description of any language can be schematized as below:

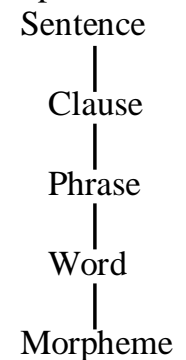

Such grammatical description is always in ascending order, that is, from morphemes, words etc. Morphemes are themselves short sequences of phonemes, thus it is important to begin from a phonological description (phonemes) to a mophological description (morphemes / words).

\section{Methodology}

The methodology adopted in this paper is both descriptive and analytical. The collection of data took place in Ikhin and Ibadan.The analysis presented in this paper is based on the quantity of tape- recorded text materials. Data were obtained from seven purposely selected native speakers in Ikhin town and one from Ibadan, using the 1000 wordlist of the Summer Institute of Linguistics and the University of Ibadan wordlist of 400 basic items. This method has assisted in unveiling speech variation among the various speakers. Additional data were collected from traditional stories, conversations, descriptive statements and isolated, unelicited utterances. The data were analysed using the speech filing system of the computerised speech laboratory.

\section{RELATED WORKS}

Literature on Ikhin language is rare. Folarin (1982) is a Master's project and is the only extant linguistic study on this language. It dwells mainly on the Phonetics of the language. Apart from the very useful auditory and instrumental study of the sounds of this language and the identification of two basic tones, high /H/ and low /L/, little is said about the various tonal and segmental processes in the language.

There have been various studies on Edoid languages in which noun class system has been exhaustively discussed. However, none has made mention of Ikhin noun class system. This paper is the first work on the noun class system of Ikhin.

\section{NOUN STRUCTURE}

Nouns and their internal structure will be given attention in this paper. Morphology is concerned with the internal structure of words, and how words can be formed. It is usual to recognize three different word formation processes.

(1) Inflectional processes, by means of which a word is derived from another word form, acquiring certain grammatical features but maintaining the same part of speech or category (e.g walk, walks)

(2) Derivational processes in which a word of a different category is derived from another word or word stem by the application of some process (e.g grammar $\longrightarrow$ grammatical, $\longrightarrow$ grammaticality)

(3) Compounding, in which independent words come together in some way to form a new unit (buttonhole).

Examples of derivational affixes can be found in the derivation of nouns and gerundive nominals from verbs in Ikhin.

$\begin{array}{llll}\text { AFFIX } & \text { CHANGE } & \text { EXAMPLES } & \text { GLOSS } \\ \text { e- } & \text { verb to noun } & \text { vújè/ èvujé } & \text { Open/Opening } \\ \text { e- } & \text { verb to noun } & \text { jà/ èjá } & \text { Drink/Drinking }\end{array}$

In Edoid languages "most roots (verb or noun) are monosyllabic, consisting in CV". (Westernmann and Bryan, 1952). The prevalence of second syllables in stems and the use of noun prefixes and concord prefixes lend a complexity of morphology to the Edoid languages of a kind not frequently associated with 'Kwa' languages. (Elugbe,1986). In all branches of the Niger-Kordofanian language family, with the exception of Mande, it is typical that a noun in its simplest form can be analysed as consisting of the stem and an affix. (Welmers, 1973).

Egbokhare (1990) claims that "in a number of West African languages, such affixes are prefixes which distinguish number". Thus Ikhin also has affixes which are noun prefixes.

\section{A. Number}

In Ikhin, majority of the nouns are inflected for number by means of prefix vowel alternation. Thus, the difference between the singular and plural forms is marked by a difference in the prefixes the nouns take.

For example:

(1) (a) i) '̀-bò 'native doctor' è-bò 'native doctors' 

ii) ù-gbằ 'thorn'
i-gbằ 'thorns'

A look at the singular-plural pairs shows that the following pairs exist:

(b)
$\mathrm{u} / \mathrm{i}$
$\mathrm{o} / \mathrm{i}$
$\varepsilon / \mathrm{i}$
$\mathrm{a} / \mathrm{i}$
$\mathrm{o} / \mathrm{e}$
o/e
$\varepsilon / \mathrm{e}$

On the basis of the above information, we can say that the plural morphemes are /i/ and /e/ and that others are singular morphemes. These patterns do not reveal a purely phonologically determined number system. For example, we have $\varepsilon / \mathrm{i}, \mathrm{o} / \mathrm{i}$ and then $\varepsilon / \mathrm{e}, \mathrm{o} / \mathrm{e}$. There is, therefore, no way of phonologically explaining this class pairing. It is not possible to say that non-low vowel attracts [i] and low vowel attracts [e]. It must be assumed, therefore, that this is an evidence of a richer noun classification system of an earlier stage in the history of the language. Nonetheless, it seems obvious that we can say there were two alternants of the plural morphemes [i] and [e] which may be reflexes of an earlier i/e.

Elugbe (1989) confirmed that proto-Edoid [*e] became [e] in all environments in North Central Edoid. Other North Central Edoid languages include Edo (Bini), Esan, Yekhee (Etsako), Emai and Ghotuo. Typical singular-plural pairings are exemplified in the examples below.

\begin{tabular}{|c|c|c|}
\hline & Singular & Plural \\
\hline ii) & j̀-bò 'native doctor' & è-bò 'native doctors' \\
\hline iii) & ù-gbằ'thorn' & i-gbằ'thorns' \\
\hline iv) & $\grave{\varepsilon}$-we 'goat' & è-wè 'goats' \\
\hline v) & ò-kò 'mortar' & è-kj̀ 'mortars' \\
\hline i) & ò-kpòsò 'female' & ì-kpòsò 'females' \\
\hline vii) & j̀-móhè'boy' & ì-móhè'boys' \\
\hline
\end{tabular}

However, there are also nouns which are not inflected for number but in constant forms. These have the same vowel prefix in their singular and plural forms:

\begin{tabular}{|c|c|c|}
\hline \multicolumn{3}{|c|}{ ù-só } \\
\hline ix) & à-k亏े'' & \\
\hline $\mathrm{x})$ & i-bùbù & \\
\hline xi) & ì-kè & \\
\hline xii) & $\grave{\varepsilon}-\grave{o}$ & \\
\hline
\end{tabular}

Thus, each noun class set up in this study (as shown below) includes the singular and plural prefix pair of each noun. Vowel harmony is not a prominent feature in Ikhin. However, vestiges of harmony are observed in the patterning of vowels in nouns and in the way vowels alternate in prefixes during plural formation as shown in the following paired classes.

\section{Singular/Plural classes}

CLASS 1:u-/i-

Parts of the body

(2) a) i) - $\quad$ ko 'stomach (intestine)'

ii) :- gwa 'knee'

Man made objects: :

b) i) -kpò 'cloth'

ii) -yòyò 'door way'

iii) -íkhuั̀ 'medicine'

Animals and animal parts:

c) i) -kj 'he-goat'

ii) -yù 'vulture'

Plants and parts of plants:

d) i) 'ságùò'groundnut'

ii) -'kpá 'seed'

Insects

e) 'sù 'Mosquito'

Natural Phenomenon

f) 'kì 'Moon'

CLASS 2: a-/i-

Plants and parts of plants

i) -sì̀ 'Pepper'

ii) 'tábà Tobacco' 
Parts of body:

h) -tìkpóhò 'Buttocks'

Man made objects:

i) - yàĭ 'Knife'

CLASS 3: $\quad \varepsilon-/ i-$

Man made object:

j) - kpà 'bag'

Abstract:

k) - yè̀̀ 'lie'

CLASS 4: o-/e-

People:

1) i) -móhè 'Man'

ii) -rùa 'In-law'

iii) : sè 'Friend'

iv) :- rè 'Guest'

Part of plants:

m) i) - gèdè 'plantain'

ii) - mòká 'Orange'

Man made objects:

n) i) - pì̀ 'Machet'

ii) :- xòrò 'Mud'

CLASS 5: o-/i-

People:

o) i) 'kpòsò 'Female'

ii) -yì 'Thief'

Man made objects:

p) - dí 'Wall of house'

CLASS 6: $\quad \varepsilon-/ \mathrm{e}$

Animals:

q) i) -la 'cow'

ii) - ¿́c̀ 'Snake'

Natural phenomenon:

r) - dà 'River'

Man made objects:

s) - gùè 'hoe'

CLASS 7: o-/e-

Man made objects:

t) i) 'gùà 'farm implement'

ii) - hìsà 'broom'

Animal and animal parts:

u) i) - fè 'rat'

ii) 'xùà 'horn'

Plant:

v) i) 'rà̀'tree'

ii) -bè 'leaf'

\section{Single class}

The single classes are each identified by single unpaired prefixes. They contain mass, abstract and some countable nouns which are pluralised through the addition of number.
a. i) /úsó/ + /evà
ii) /úsóevà/ 'two heads'

Nouns that refer to parts of the body, parts of the plants, animals, man made objects are countable, while mass nouns, abstract nouns, the nouns which refer to the natural phenomena group are uncountable. Some of these fall within the group called 'others'.

CLASS 8: u-

Parts of body

b) i) 'só'head'

ii) 'nù'mouth'

CLASS 9: i-

Parts of body: 
c) i) -gwè 'nose'

ii) -xèrè̀' penis'

Man made objects:

d) 'bàtà 'shoe'

OTHERS:

e) i) -tà̀ 'story'

ii) -yì 'guinea corn'

iii) 'rà 'father'

iv) '-kpèkpéyè 'duck'

v) -sò 'feaces'

CLASS 10:

Natural phenomena:

f. i) -kŭ̀ 'sea'

ii) -óyò 'day'

Abstract:

g. - sà 'hunger'

Parts of body:

h. :- bò 'arm'

CLASS 11: e-

Man made objects:

i) i) -gùà 'village'

ii) -yòyò 'road'

Others:

j) i) 'rà 'name'

ii) -gbè 'body'

CLASS 12: a-

Parts of body:

k) i) -gbà̀ 'jaw'

CLASS 13: ee-

Others:

1. i) - nè 'four'

CLASS 14: 0-

Seasons:

m. i) -rùámè 'rainy season'

ii) - wòvo 'dry season'

CLASS 15: oi-

Others:

n. 'hi 'fear'

\section{B. Compound Nouns}

A good number of the polysyllabic (trisyllabic) nouns are derived. Each of these nouns whether derived or not has initial vowel which is historically a class marker.

3) i ) /étùàgbằ/ < é + tù + à-gbằ

ii) 'bear' $\mathrm{np}+$ hair + Jaw

ii) /ókòc̀dà/ < ó +kò + ̀̀-dà

'canoe' $\mathrm{np}+$ motor + river

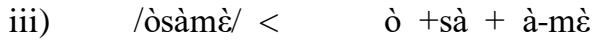

'thirst' $\quad \mathrm{np}+$ hunger + water

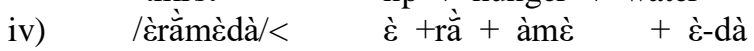

'crocodile' $\mathrm{np}+$ animal + water + river

Based on the above, noun structure may be represented with the following diagram

(4)

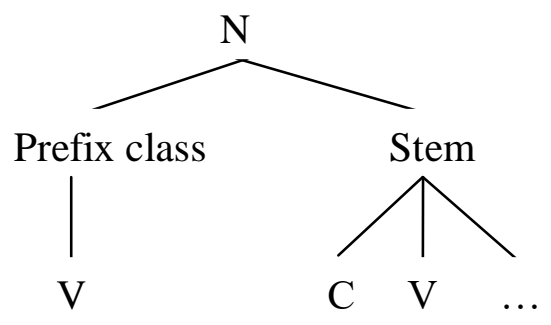




\section{Agentive Nouns}

A noun in Ikhin (most nouns are formed from verb stems) is usually of $\mathrm{v}-\mathrm{c} \mathrm{v}$ structure (the hyphen separates the prefix from the stem). Polysyllabic nouns are of the structure v - c v c v. While verbs have initial consonants, nouns on the other hand, have initial vowels. A few of these nouns are derived from the verbs by prefixing vowels to the verb stems.

Examples:

Verb prefix + stem + concord prefix + verb Agentive-Nominal

\begin{tabular}{|c|c|c|c|c|c|}
\hline (6) i) dè 'buy' & $0-$ & li & 0 & $-\mathrm{d} \grave{\varepsilon}$ & ólòdè 'buyer' \\
\hline kíc̀ 'sell' & $0-$ & li & 0 & -kíc̀ & ólókjê ‘sellers’ \\
\hline gbè 'kill' & 0- & li & 0 & -gbe & ólògbè 'killer' \\
\hline ż̀ 'build' & $0-$ & li & 0 & $-z \grave{~}$ & ólòzò 'builder' \\
\hline xà 'teach' & 0- & li & 0 & -xà & óloxà 'teacher' \\
\hline
\end{tabular}

The above involve the deletion of the vowel of the agentive stem.

\section{Personal Pronouns}

In traditional grammar, a pronoun is seen as functioning as a substitute for a noun in discourse. According to Egbokhare (1990), an adequate description of the pronominal system of a language entails a specification of the forms which are realized in various environments and where necessary a specification of their relationship. The pronoun in Ikhin is a nominal which can be inflected both for person and number.

The following is the paradigm of the subject pronominal:

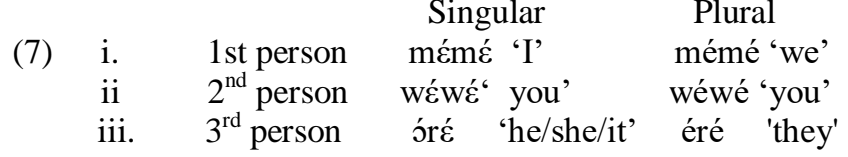

The above paradigm reveals that the subject pronominals are inflected both for person and number.

Examples:

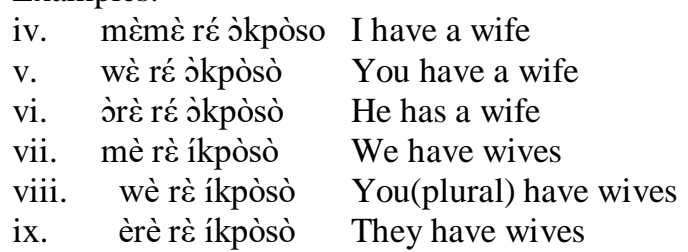

On the other hand, the pronominals have the following paradigm when functioning as object.

\begin{tabular}{|c|c|c|c|c|}
\hline & & Singular & Plural & \\
\hline $\mathrm{x}$ & 1st person & mímé'me’ & mímé 'us/our' & \\
\hline & $2^{\text {nd }}$ person & wéwé'you’ & wéwé 'you/your’ & \\
\hline 11. & $3^{\text {rd }}$ person & òsò 'him/his & 'them/their' & (Possessive) \\
\hline
\end{tabular}

Examples:

Objects

xiii. ó fì mè èmì He beat me

xiv. ó fì wè He beat you

Xv. mí fì òsò I beat him

xvi. ó fí èmì He beat us

xvii. òbè ní ìsé érò The book is their own (Possessive)

On the contrary, the above show that the morphological shape of the second person remains constant in both the subject and the object positions. This is an exception which is not unusual as the same is found in English language where the second person pronoun 'you' has the same morphological shape in every environment it occurs.

\section{E. Numerals}

Numerals are made up of prefixes and stems. The numeral forms from one to ten are simple forms while those from twelve upwards are compounds of one kind or the other:

Examples:

\begin{tabular}{|c|c|}
\hline 1) & /okpà/' \\
\hline ii) & /èvà/ \\
\hline iii) & /èhà/ \\
\hline$i v)$ & /ènغ̀/ \\
\hline v) & /íkhè/ \\
\hline vi) & /éhà/ \\
\hline v) & /ìkhirà/ \\
\hline vi) & /inc̀nغ̀/ \\
\hline $\mathrm{V}$ & /it_írí/ \\
\hline
\end{tabular}


x) lìgbè/ 'ten'

The numeral forms from twelve to fifteen (12-15) are formed by the addition of the Ikhin word for ten /ìgbè/ to the simple form for one through five which are listed above thus making them derived compound forms.

Examples:

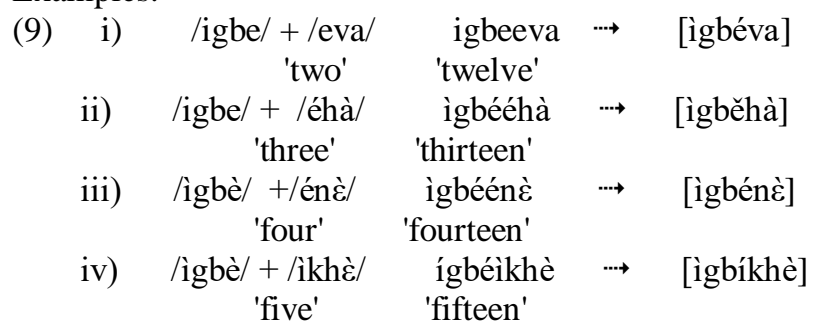

However, numeral forms from sixteen to nineteen (16-19) are exceptions to this derivational process, as shown below:

v) kòíhínhòsùe 'sixteen'

vi) kòíháhsùè 'seventeen'

vii) kòíváhòsùè 'eighteen'

viii) kòkpáhòsùe 'nineteen'

Note that the form for eleven is not described because it also does not have similar relationship with others. For instance, the form for eleven is /igbéùó/. If we say that /igbè/ means 'ten', then to what numeral form or number do we want to assign $/ \mathrm{u} /$ ?

This also constitutes an exception. The numeral form for twenty is /ègbj/ while the numeral forms for forty, sixty, eighty etc. are formed by multiplication, which involves suffixing the basic numerals to the form for twenty.
ix)
/ègbj̀/ + lèvà/ $\rightarrow$
twenty two
ègbòvà $\cdots \rightarrow$
[ègbèvà]
$\mathrm{x})$
/ègbj̀/ + /éhà/
'forty'
xi)
twentythree
ègbóéhà $\rightarrow$ [ègběhà]
'sixty'

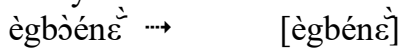
twentyfour
'eighty'

\section{THE DETERMINERS}

Noun phrases consist of a head noun and various sorts of modifiers. The modifiers that will be primarily discussed here are the determiners, a class of modifiers that includes the articles 'ò-lì', demonstratives 'ò-nī, j̀-na, è-nà, è-nì and possessive 'mè', 'mà' etc. In Ikhin, the semantic distinction between definite and indefinite articles is not marked overtly in any obvious way as it is in English by contrasting 'a' and 'the' rather both are presented as /o-li/ in Ikhin.

\section{A. Article}

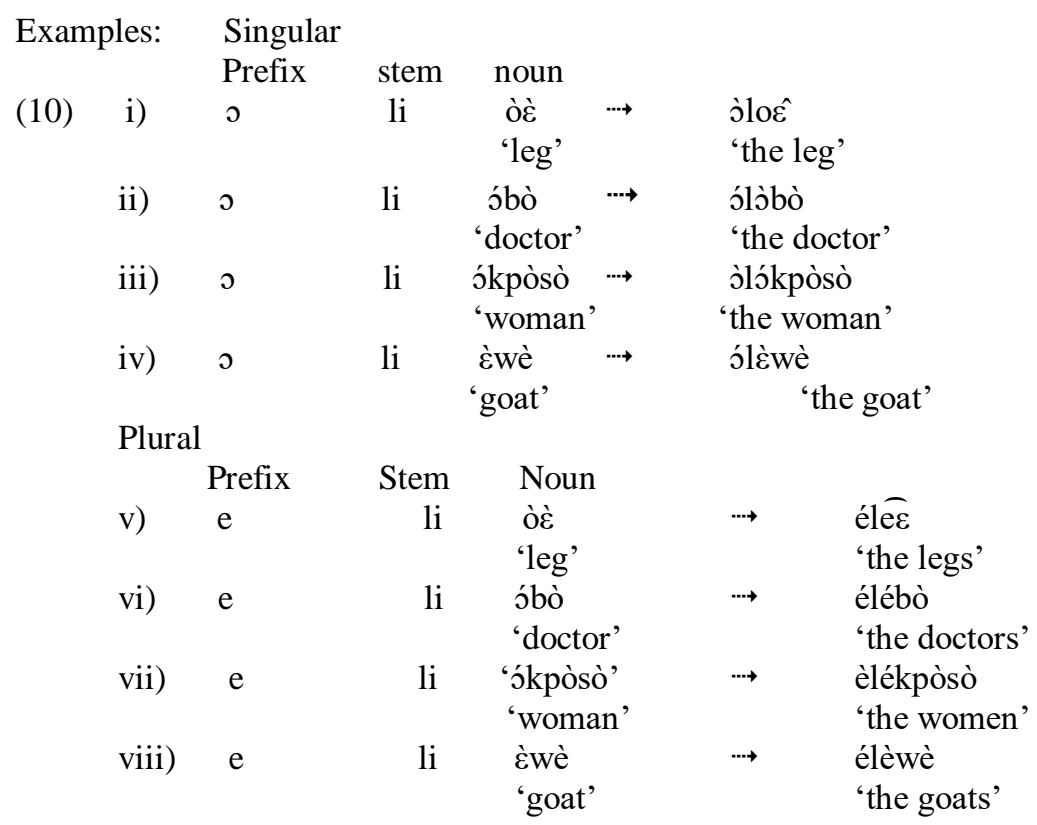

\section{B. Demonstrative}

Demonstratives are modifiers that can be used in pointing things out such as 'this' /ona/ and 'that' /oni/, and as a result of their meaning, demonstratives are always definite and they are post modifiers, occurring after the head nouns. In 
using these demonstratives, Ikhin distinguishes between near /ònà/ 'this' and far /ònì// 'that'. This can be looked at from the point of view of the speaker and the hearer.

Example:

Singular
Noun

i) ò̀̀

'leg'

ii) ò̀े

Plural

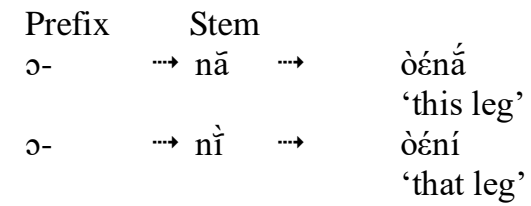

e- $\quad \rightarrow$ nà̀ $\quad \rightarrow \quad$ àènă

'these legs'

e- $\quad \rightarrow$ nì̀ $\quad \rightarrow \quad$ àènî́

those legs'

Other examples are:
iii) àè
iv) àè 'legs'

'this doctor'

'these doctors'

'that doctor'

'those doctors'

'that basket'

'this basket'

'that wall'

'this wall'

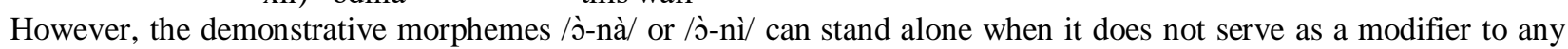
noun. Compare for instance, the following pairs of sentences:
1a. mí dé áß̇̀ onì (nominalised)
I buy + past house that
I bought that house
b. mí dé onì (non-nominalised)
I buy + past that
I bought that
2a. mí dé áßè j̀nà (nominalised)
I buy + past house this
I bought this house
b. mí dé ònà (non-nominalised)
I buy + past this
I bought this

As said earlier, the demonstrative is not monomorphemic, it consists of the prefix /ò-/ and the stem /-nà/. /o-/ is a singular prefix which becomes /e-/ in the plural so that when we have the plural demonstrative, plurality is marked in the prefix, thus the prefix serves as a concord marker. Examples:
1a. mí dé íßèènì
'I bought those houses'
b. mí dé áßè ònì
'I bought that house'
2a. mí dé í $\beta \grave{\varepsilon}$ ènà
b. mí dé áßè ònà
'I bought these houses'
'I bought this house'

\section{Possessive}

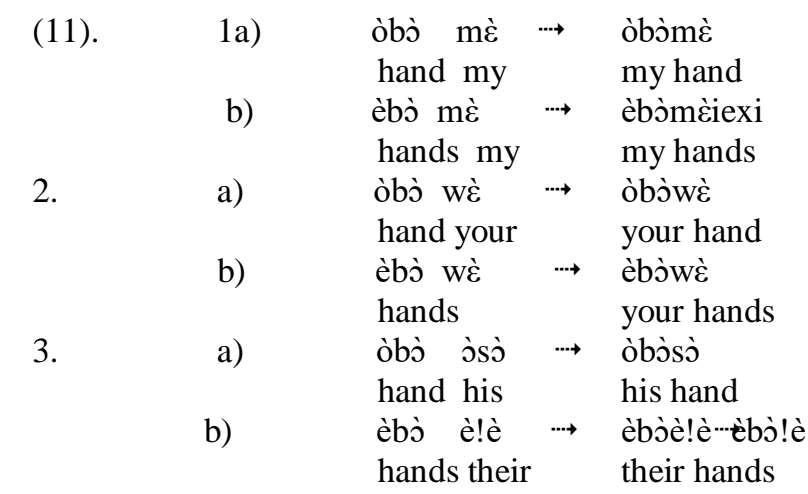

In the paradigm for the articles, the stem vowel is deleted at word boundary while in the demonstratives, the prefix vowel of the demonstrative is deleted. Also in the possessive, the prefix vowel is deleted as shown in the third person plural and singular possessives. It must be noted, however, that deletion does not apply to other forms of possessive 
because they are monosyllabic with CV syllable structure whereas the third person possessive has V-CV structure like other forms of determiners.

\section{CONCLUSION}

This study confirmed that Ikhin is a typical African language with some similar grammatical features of Edoid origin. In accounting for how nouns and pronominals are inflected for number and person, this paper established that the plural morphemes are /i/ and /e/ and that others are singular morphemes. Vestigial evidence of concord which is normally the hallmark of a noun class system was confirmed in modifiers, such as demonstrative and possessive pronouns.

Regarding pluralisation, the paper demonstrated that plural marking is optional in Ikhin but that when nouns are marked for plural, there are three different ways in which this is carried out. First is through a contextually determined plurality. These are cases where there is no overt plural marking, as such; a noun can be interpreted as singular or plural e.g. [ú-só] 'head', [à-kう̌] 'tooth'. The second strategy is a lexically determined plurality. These are cases where nouns take quantifiers and numerals. The third strategy is a morphologically determined plurality by means of a prefix vowel alternation e.g.

[ò-ră] 'tree'
[è-rā] 'trees'
[غ̀-wè] 'goat'
[è-wè] 'goats'

\section{REFERENCES}

[1] Blench, R. (1989). New Benue - Congo. A Definition and Proposed Internal Classification. Arbeits Papiere. 17: 115 - 147

[2] Egbokhare, F. (1985). "Vowel Elision in Emai' Unpublished M.A Project, University of Ibadan

[3] Egbokhare, F. (1990). "A Phonology of Emai". Unpublished Ph.D Thesis, University of Ibadan.

[4] Elugbe, B. (1989). Edoid. In J.T. Bendor-Samuel (ed.). The Niger-Congo Languages, 291-304. New York: University Press of America.

[5] http://www.ling.mq.edu.au

[6] Lewis, A. A. (2013). North Edoid relations and roots. Doctoral dissertation, University of Ibadan

[7] Oladimeji, O. (2010). A Phonology of Ikhin, an Edoid Language in South-South, Nigeria. Unpublished Ph.D Thesis, University of Ibadan.

[8] Oladimeji, O. (2013). The Tone System of Ikhin. Open Science Repository Language and Linguistics. www.open-sciencerepository.com

[9] Website of the Department of Linguistics, Macquarie University. http://www.ling.mq.edu.au.

[10] Welmers, W. (1973). African Language Structures. Los Angeles: University of California Press.

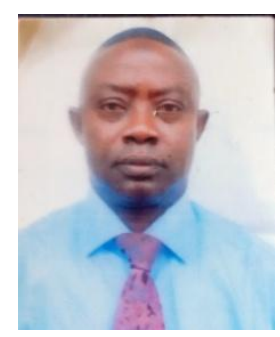

Olaide Abduwaheed Oladimeji was born in Ibadan, Nigeria 1969. He received his $\mathrm{PhD}$ degree in Linguistics from University of Ibadan in 2010.

He is a lecturer 1 in the Department of Linguistics and Languages, Federal University, Oye-Ekiti, Nigeria. His research interests include Phonology and Syntax of African languages.

Dr. Oladimeji is member of Linguistics Association of Nigeria.

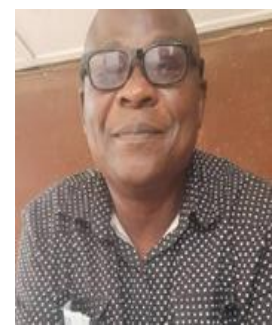

Tajudeen Bolanle Opoola was born in Oyo, Nigeria in 1959. He received his $\mathrm{PhD}$ degree in Linguistics from University of Calabar, Nigeria in 2001.

$\mathrm{He}$ is currently a Professor in the Department of Linguistics and Languages, Federal University, Oye-Ekiti, Nigeria. His research interests include Applied Linguistics and African languages.

Professor Opoola is a member of Linguistics Association of Nigeria and Patron, Association of Nigerian Authors, Oyo State branch, Nigeria. 